\title{
STRATEGIES FOR THE DEVELOPMENT OF THE VALUE OF THE MINING-INDUSTRIAL HERITAGE OF THE ZARUMA-PORTOVELO, ECUADOR, IN THE CONTEXT OF A GEOPARK PROJECT
}

\author{
GRICELDA HERRERA FRANCO ${ }^{1}$, PAÚL CARRION MERO ${ }^{2}$, FERNANDO MORANTE CARBALLO $^{2}$, \\ GEANELLA HERRERA NARVÁEZ ${ }^{3}$, JOSUÉ BRIONES BITAR ${ }^{3} \&$ ROBERTO BLANCO TORRENS ${ }^{4}$ \\ ${ }^{1}$ Universidad Estatal Península de Santa Elena, Facultad de Ciencias de la Ingeniería, La Libertad, Ecuador \\ ${ }^{2}$ ESPOL Polytechnic University, Escuela Superior Politécnica del Litoral, Centro de Investigación y Proyectos \\ Aplicados a las Ciencias de la Tierra, Guayaquil, Ecuador \\ ${ }^{3}$ BIRA Bienes Raíces S.A., Zaruma, Ecuador \\ ${ }^{4}$ Instituto Superior Minero Metalúrgico, ISMM, Facultad de Geología y Minas, Cuba
}

\begin{abstract}
The enhancement of heritage resources helps to promote conservation, contributes to more significant and better protection, and favors the efficient use of these resources. Many heritage works and liabilities linked to mining activity are abandoned, causing the deterioration of heritage resources that may become environmental liabilities over time. This work aims to develop strategies for the development of the Mining-Industrial heritages through participatory methods for geomining enhancement and development of places in the Zaruma-Portovelo area. The proposed methodology consists of: (i) The creation and development of a database with several publications and documents that register the Mining-Industrial heritage sites; (ii) The assessment of mining-industrial sites based on criteria or methodologies proposed by other authors; (iii) Focal group work considering: (a) The identification and cataloging geosites of interest, (b) The creation and/or development of museums, tourist mines, mineral routes or geoparks in which the natural and geological-mining factors complement each other and (iv) SWOT analysis and matrix which provides several strategies for value-making of geomining heritage and its promotion in the development of geotourism in a project proposal for Zaruma and its surroundings. In conclusion, this work includes twelve unified mining sites in the Proposal for Geopark 'Ruta del Oro,' as a strategy to guarantee the conservation of heritage values and contribute to local development and geotourism.
\end{abstract}

Keywords: conservation, environmental liabilities, geosite, geotourism, Mining-Industrial heritage.

\section{INTRODUCTION}

Heritage constitutes the historical memory of a nation and it is the fundamental pillar to build a culture that stands out in attitudes, behavior and implicit values acquired by a man, as a member of a society over time. These values are the result of their relationship with the environment, which makes it valid for sustainable development and reveal through assets with an attractive appeal, either because of its outstanding artistic value or its originality, rarity or extravagance [1]. In this area of study, the population plays an essential role in the contribution of the image given to a site; therefore, rescuing the heritage derives from a committed perspective that freezes 'valuable' situations. Restorations 'value' the elements considered the most attractive for highlighting the authenticity of a place. The knowledge of history has all the elements of the awareness process that a community has [2]. Validating that knowledge is a complex task because it comprises conservation strategies and heritage interpretation. These elements consider the value-added defined as the interpretation and presentation of different values given to the patrimony such as material, symbolic, emotional, social, and educational or use value [3]. 
The existence of a culture without heritage and a society without memory is impossible [4]; that is why, the cultural heritage of a country or region is constituted by all those elements and tangible or intangible manifestations produced by societies, result of a historical process that identifies and distinguishes that country $[5,6]$. However, social value is the key that makes heritage an essential reality for the understanding of culture through societies capable of transmitting their value to future generations. There are different activities for which the heritage is reflected. In this case, we will focus on the industrial activities that have provided over the years a great importance in different mining areas, which have led the creation of an industrial heritage closely related to the mining heritage. It includes surface and subsurface level, hydraulic installations, transport, machinery, documents or objects related to previous mining activities with historical, cultural or social value $[5,7,8]$. This s value allows access to new geotouristic destinations for the sustainable development of a region.

In Ecuador, there are many places with outstanding features to mining sites. In El Oro province, precisely the district Zaruma-Portovelo is a study area, where mining activity stands out since the Pre-Inca stage. In the fifteenth century, the Inca Tupác Yupanqui was sent to the conquest of the north of his empire $[9,10]$. In the time of the colonization, the Spaniards ground the quartz for obtaining the mineral and extracted gold of three pounds of weight given as a gift to the King of Spain. The provenance was from the 'El Sexmo' gold mine [8]. The rehabilitation of this mining area began in 2002 by the company BIRA S.A. After this initiative, 'El Sexmo' may become a cultural tourist attraction that associates mining with a producing industry for the country development [11]. Recently, there has been a resurgence of mining in megaprojects that have prompted the Ecuadorian government interest in these social sectors [12].

This study seeks to rescue Zaruma-Portovelo historical values and geotourism places, where mining activity plays a vital role. Mining phases of prospecting, exploration, benefit, smelting, refining and marketing of minerals $[5,7,13,14]$ are used for local profit-making purposes. Taking advantage of this knowledge, this study advocates labor reintegration after the closure of mines as a patrimony to promote geotourism along with the relocation of human resources in existing mines [15]. Furthermore, the industrial heritage comprises all the material and immaterial vestiges inherited by industrial activities. Industry is the production of an item for its commercialization, not for self-consumption [16]. The industrial-mining heritage becomes the architectural, museum or recreational point of view along with the rehabilitation of areas damaged by the use of post-mining land. This gives value not only to the old industrial establishments but also to the vast industrial facilities and the scientific establishments that become the object of attention and visit as indicated by the Spanish geographer Horacio Capel in [17]. This corresponds to the mining-industrial heritage where activities related to geotourism are addressed to achieve sustainable development.

The interest in rescuing Zaruma and Portovelo mining-industrial heritage is based on the proposal Geopark 'Ruta del Oro'. We considered twelve geosites of interest, which contribute to the enrichment of historical knowledge, education, cultural identity and economic reactivation of the populations $[18,19]$. These locations have benefited from the mining activity with the creation of development strategies compatible with their own history and transcendence.

These strategies arise from alternative activities such as the creation and development of museums, tourist mines, mineral or Geopark routes in which the natural and industrial-mining factors complement each other. Mining sustainability is achieved through policies that allow communities to take advantage of this type of activity after depleting the deposits, the 
knowledge acquired and the infrastructure [20]. The process takes place, through the enhancement of mining interest sites, whose development paths are focused on the analysis of the positive impacts that mining generates on the environment. Another consideration is the compensation of irreversible impacts in order to exploited potential cultural heritage that tourists give to the tangible and intangible heritage of industrialization [21, 22].

\section{STUDY AREA}

El Oro province, located in the south of Ecuador, is divided into three zones: the coastal plain or lower part, the upper part and the Jambelí archipelago. The second zone is called the Orense Plateau because it is located in Los Andes Mountain Range, characterized by ancient volcanism. These mountain ranges are undulated and it is formed by sites such as Saracay, Balsas, Marcabelí, Piñas, Atahualpa, Portovelo, Zaruma up to the ridges of the Hoya Puyango [18]. The study area is Zaruma and Portovelo, the name Zaruma comes from two Quechua words SARA: head and UMA: corn (head of corn), and it was founded by Alonso de Mercadillo, the same founder of Spain by order of the Spain King [19]. Zaruma and Portovelo are the oldest mining region in the country because they belongs to one of the five mining districts of more considerable antiquity and importance. The district is limited to the North with Guayas and Azuay provinces, South and East with Loja and Northwest with Guayaquil Gulf [20, 24].

Currently, Zaruma has $659.40 \mathrm{~km}^{2}$ of extension and a population of 24097 inhabitants [18]. Its auriferous wealth is the primary source of work for inhabitants and immigrants. In Zaruma, $24.11 \%$ of the population works in mines equivalent to 2369 jobs. In Portovelo, $32.85 \%$ are dedicated to mining with 1692 jobs, which make a total of 4061 jobs [21]. Because in the Zaruma sector there are non-technical mining practices and outside the law which have caused the mines that were in operation have been closed, since they have caused environmental and social impacts. Therefore, the Ecuadorian government has decreed an extension of the mining exclusion zone. This fact emphasizes that in the Zaruma sector there has been no technical mine closure process, and this process, in the current situations, becomes essential. The closure of mines is a technical process that from its inception foresees the conditions in which the authorized sectors must be enabled for later use and in the best safety conditions, so that the closure of mines is closely linked to the processes of clean energy production.



Figure 1: Zaruma-Portovelo mining-industrial sites [23]. 
Therefore, we have seen the need to look for other sources of income such as the commercial, agricultural, livestock, craft, and tourism sectors, being tourism our subject of interest. For this reason, in this work are considered twelve mining-industrial sites rich in heritage that promote geotourism in the region, such as Mina Turística el Sexmo, Museo Geocientífico y Mineralógico Magner Turner, Museo Municipal de Zaruma, Escultura en Honor al minero, Monumento al minero en Portovelo, Manantiales de aguas termales Portovelo, Mina Vizcaya, Minas Antiguas de Miranda, Minas de Oro Reina de Fátima, Antigua Planta de Beneficio de la SADCO, Plantas de beneficio Vía Portovelo-Pache and Planta Hidroeléctrica El Pache. 'Figure 1 shows the mining-industrial sites of the study area'.

\section{METHODOLOGY}

To ensure the results of this study, a methodology composed of four phases was proposed: (i) The creation and development of a database, publications and others that register mining-industrial heritage sites, thus ensuring up-to-date information from various authors; (ii) The assessment of mining-industrial sites was based on methodologies proposed by authors such as Esther et al., [22] and the methodology of Inventario Español de Lugares de Interés Geológico (IELIG) [5]. The first corresponds to a methodological guide for the integration of mining heritage in the environmental impact assessment, where Mining Heritage Sites called LIPMs, which include the industrial part, covers two factors: (1) LIPM intrinsic value, making relevance to the mining-industrial aspects and (2) use-value of the LIPM. In this way, with the collaboration of experts such as Magner Turner, Tito Castillo, Vicente Figueroa and Carmen Macas, together with the necessary fieldwork, we obtained the assessment of the sites global interest $(\mathrm{Vg})$ or merit of conservation through the establishment of weights given to each one according to [22]. The elements that are equal or greater than 300 points will be considered 'Very high' mineral heritage places of interest. With values between 300 and 200 will be of 'High' interest. The scores between 100 and 200 will be of 'Medium' interest, and the elements that do not reach the 100 points will be of 'Low' interest.

Subsequently, the change in the value of a LIPM is estimated after the execution of a project, resulting in the loss of its conservation value in the following categories: remarkable, significant, moderate and slight value, being 'remarkable' the consequence of a substantial improvement of its intrinsic value or its possibilities of use. According to these criteria, the resulting state of impact is obtained based on the two previous results together with the Regulation of Environmental Impact Assessment (EIA). The state obtained for each of the LIPM will be qualified as: state not significant, compatible, moderate, severe and critical, where the latter is the one in which the decrease in the value of the LIPM is comparable with its destruction or with a loss of value that cannot be assumed [22]. Likewise, the methodology developed in [5], states that by measuring the degree of scientific interest (Ic), educational interest (Id) and the tourist interest (It), the global interest value, similar to the previous methodology, is obtained.

The phase (iii) includes the work of a focal group considering: (a) The identification and geosites of interest cataloging, (b) The creation and development of museums, tourist mines, mineral or Geopark routes. For the presentation of results, in phase iv) the preparation of an analysis of Strengths, Weaknesses, Opportunities and Threats (SWOT) and its corresponding matrix TOWS is proposed, in which several strategies for the implementation of the value enhancement of the mining-industrial heritage and its impact on the growth and development of geotourism in a project proposal for Zaruma. Figure 2 summarizes the methodology proposed in this study. 




Figure 2: Methodology flowchart used for the research.

\section{RESULTS}

After identifying the area of this study and having compiled all the bibliographical information available, twelve geosites of mining-industrial interest could be registered and presented in Table 1.

The evaluation of these places was done through surveys of experts from the sites of interest. The researchers applied the methodology proposed in [22] to find the global value $(\mathrm{Vg})$ of each of the geosites to be considered LIPMs at present. They are valued in the category of 'Very high' interest to Plantas de beneficio Vía Portovelo-Pache, Antigua planta de beneficio de la SADCO, Minas antiguas de Miranda, Museo Municipal de Zaruma, Museo geo-científico y mineralógico Magner Turner y la Mina turística 'El Sexmo' (Fig. 4) with a score of 330, 300, 307.5, 320, 330 and 300, respectively. To 'High' interest category belong Planta Hidroeléctrica El Pache, Minas de Oro Reina de Fátima, Mina Vizcaya, Manantiales de aguas termales Portovelo, Monumento al minero en Portovelo and Escultura en honor al minero en Zaruma with a score of 245, 251.5, 277.5, 244, 237.5 and 237.5, respectively. The LIPMs selected are in the two highest categories, which make them conservation icons (Fig. 3).

Once the LIPMs Global Value has been obtained, they go through the calculation of the loss of their conservation value imposed by the execution of a project. In this new evaluation of the LIPM, Antigua Planta de beneficio de la SADCO with 37\%; la Planta Hidroeléctrica El Pache, Planta de beneficio Vía Portovelo-Pache, Minas de oro Reina de Fátima, Mina Vizcaya and Manantiales de aguas termales Portovelo with $27.25 \%$ entered the 'Significant' category. In the 'Moderate' category, we found Minas Antiguas de Miranda with $24.5 \%$ and 
Table 1: List of mining-industrial sites of interest and their location in the study area.

\begin{tabular}{lllll}
\hline $\mathbf{N}^{\circ}$ & Geosite & $\begin{array}{l}\text { Main } \\
\text { interest }\end{array}$ & Location & Canton \\
\hline 1 & Mina Turística el Sexmo & Mining & Zaruma & Zaruma \\
2 & $\begin{array}{l}\text { Museo Geocientífico y Mineralógico } \\
\text { Magner Turner }\end{array}$ & Mining & Portovelo & Portovelo \\
3 & Museo Municipal de Zaruma & Mining & Zaruma & Zaruma \\
4 & Escultura en Honor al minero & Mining & Zaruma & Zaruma \\
5 & Monumento al minero en Portovelo & Mining & Portovelo & Portovelo \\
6 & Manantiales de aguas termales Portovelo & Mining & Portovelo & Portovelo \\
7 & Mina Vizcaya & Mining & Zaruma & Zaruma \\
8 & Minas Antiguas de Miranda & Mining & Zaruma & Zaruma \\
9 & Minas de Oro Reina de Fátima & Mining & Arcapamba & Zaruma \\
10 & Antigua Planta de Beneficio de la & Industrial & Portovelo & Portovelo \\
& SADCO & & & \\
11 & Plantas de beneficio Vía Portovelo-Pache & Industrial & Pache & Portovelo \\
12 & Planta Hidroeléctrica El Pache & Industrial & Portovelo & Portovelo \\
\hline
\end{tabular}

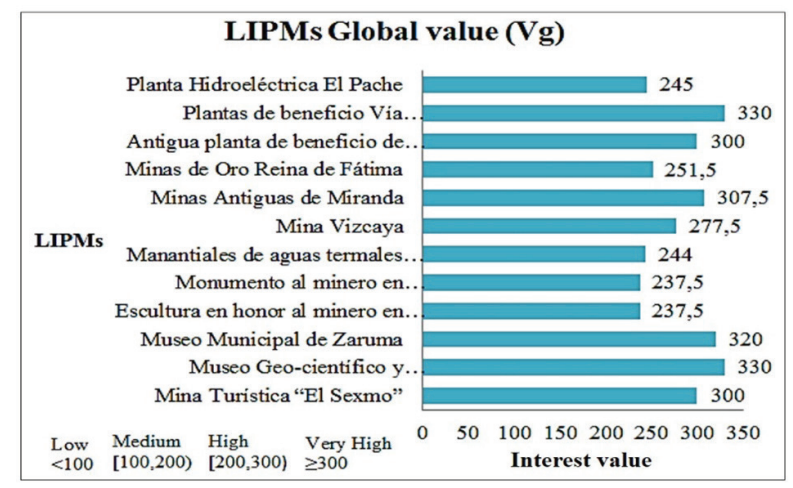

Figure 3: Global value ( $\mathrm{Vg}$ ) results of the mining heritage sites.
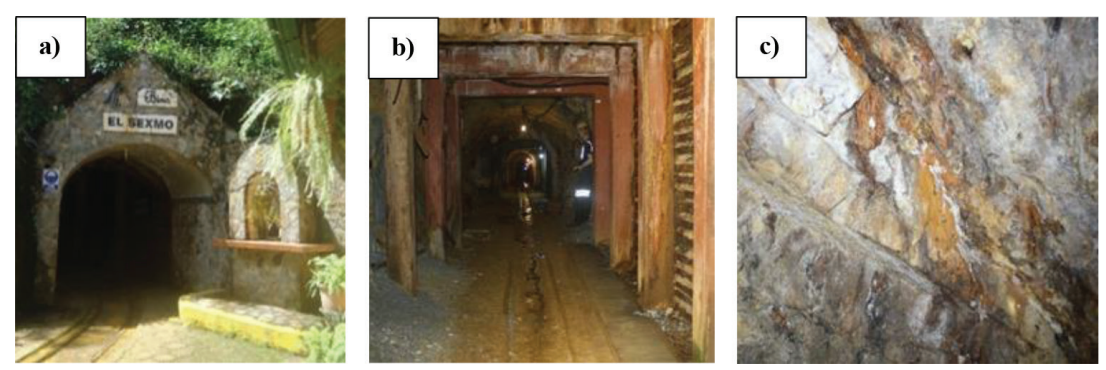

Figure 4: Example of mining site (Tourist Mine 'El Sexmo') registered in the inventory. (a) Entrance to the pit; (b) underground passage; (c) gold veins inside the mine. 
the Museo Geo-científico y Mineralógico Magner Turner with 11.25\%. Finally, in the 'Slight' category is found Monumento al minero en Portovelo, Escultura en honor al minero en Zaruma and Mina turística 'El Sexmo' with 5.5\% (Figs. 5 and 6).

The 'significant' loss of value of LIPMs is the consequence of a sensible modification of the LIPM with appreciable repercussions, in short, or long term, on its intrinsic value or possibilities of use. In those sites with a 'moderate' loss of their value, the effect may occur in the future as repercussions on their intrinsic value or possibilities of use, while those of 'slight' loss of value have slight repercussions in the future [22].

To complement this methodology, we estimated the change in value that the LIPM may take before and after the project execution and the loss of its conservation value. According to the matrix in [22], to estimate this impact, Figs. 3 and 5 are used, categorizing the geosites in the following states described in Table 2. The LIPM tolerance to negative alterations associated with a project or activity depends on the global value $(\mathrm{Vg})$ given to the LIPM. Therefore, the acceptable threshold of loss of value will be lower in the LIPM of very high and more permissive or higher in those of low value, as indicated in Table 2.

The status of each geosite can be critical, severe and moderate. For example, in 'critical' status, we found Antigua Planta de Beneficio de la SADCO due to the total abandonment of the site and the total deterioration of its infrastructure by the action of external agents. Likewise, the Plantas de beneficio Vía Portovelo-Pache are in 'critical' statusdue to the excessive pollution of its rivers, which causes a decrease in the value of the LIPM that is understood as the destruction or total loss of its conservation value, that is, permanent without recovery. In 'severe' status are the Manantiales de aguas termales Portovelo, Mina Vizcaya, Minas Antiguas de Miranda, Minas de oro Reina de Fátima and Planta Hidroeléctrica El Pache, where, the reduction of the LIPM value is evident in infrastructure, and the recovery of the conditions of the LIPM requires the adaptation of significant protective measures. In the 'moderate' status are Mina turística 'El Sexmo,' Museo Geo-científico y Mineralógico Magner Turner, Museo Municipal de Zaruma and Plantas de beneficio Vía Portovelo-Pache.

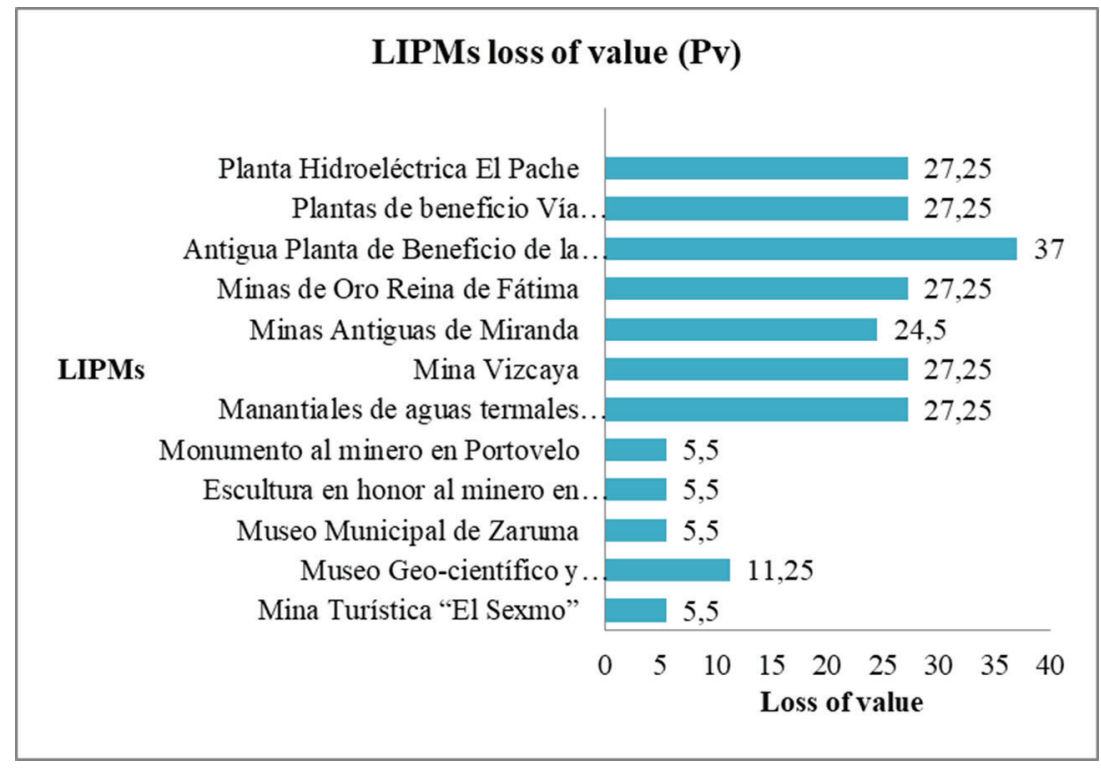

Figure 5: Loss of value results of mining heritage sites (LIPMs). 


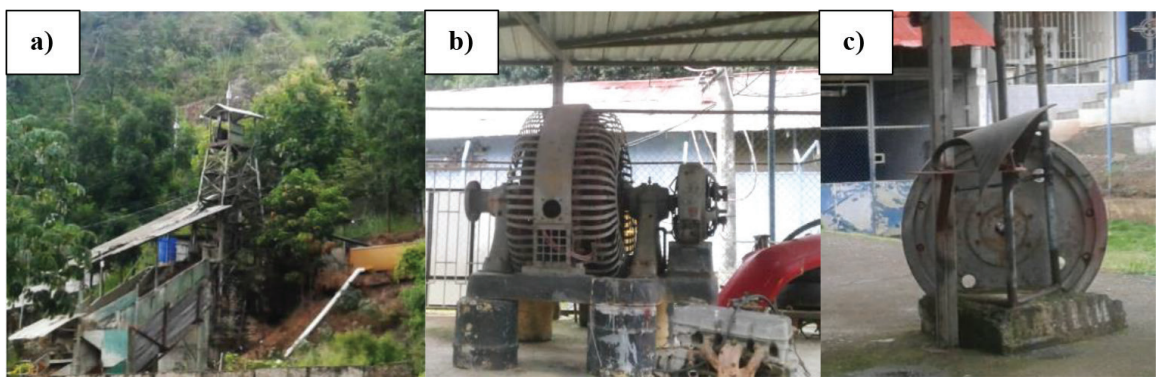

Figure 6: Industrial site example with significant value loss. (a) Old American Sink of the SADCO; (b, c) El Pache hydroelectric plant.

Table 2: Relationship of the status of the LIPM based on its loss of value due to external effects.

\begin{tabular}{|c|c|c|c|c|}
\hline $\mathbf{N}^{\circ}$ & LIPMs & $\begin{array}{l}\text { Global } \\
\text { Value (Vg) }\end{array}$ & $\begin{array}{l}\text { Loss of } \\
\text { Value (Pv) }\end{array}$ & Status \\
\hline 1 & Mina Turística 'El Sexmo’ & Very High & Slight & Moderate \\
\hline 2 & $\begin{array}{l}\text { Museo Geo-científico y Mineralógico } \\
\text { Magner Turner }\end{array}$ & Very High & Moderate & Moderate \\
\hline 3 & Museo Municipal de Zaruma & Very High & Slight & Moderate \\
\hline 4 & Escultura en honor al minero en Portovelo & High & Slight & Compatible \\
\hline 5 & Monumento al minero en Portovelo & High & Slight & Compatible \\
\hline 6 & Manantiales de aguas termales Portovelo & High & Significant & Severe \\
\hline 7 & Mina Vizcaya & High & Significant & Severe \\
\hline 8 & Minas Antiguas de Miranda & Very High & Moderate & Severe \\
\hline 9 & Minas de Oro Reina de Fátima & High & Significant & Severe \\
\hline 10 & $\begin{array}{l}\text { Antigua Planta de Beneficio de la } \\
\text { SADCO }\end{array}$ & Very High & Significant & Critical \\
\hline 11 & Plantas de beneficio Vía Portovelo-Pache & Very High & Significant & Critical \\
\hline 12 & Planta Hidroeléctrica El Pache & High & Significant & Severe \\
\hline
\end{tabular}

Forthese sites, it is suggested to establish non-intensive protective or corrective practices. Finally, Escultura en honor al minero and Monumento al minero in Portovelo are in a 'compatible' status, that is, their loss is acceptable.

\section{DISCUSSION}

The geosites and mining sites value-setting approach is reinforced by the mines closure criterion since the use of these sites as geotourism enters a very important demonstrative process what is the mines closure. Geopark proposal comprises an integrative project that seeks to make use of the previously exploited areas, and thus enabled them for new alternatives, without losing the relationship with the sector mining identity. In this way, the areas considered 
Table 3: TOWS analysis of the workshop 'Geotourism prospects in the upper part of El Oro province, Zaruma-Portovelo'.

\begin{tabular}{|c|c|}
\hline Strengths & Opportunities \\
\hline $\begin{array}{l}\text { Zaruma is considered the first Ecuador } \\
\text { Magical Town. } \\
\text { The sites of mining-industrial interest } \\
\text { in the area are accessible and with high } \\
\text { global heritage value. } \\
\text { Compatibility of conservation in the his- } \\
\text { torical and cultural wealth of the country. } \\
\text { Mining technical knowledge to be ex- } \\
\text { ploited. } \\
\text { Portovelo highlights its mining history } \\
\text { with the American company SADCO. } \\
\text { The mining resources in the area link the } \\
\text { community with its history. }\end{array}$ & $\begin{array}{l}\text { Expansion of tourism. } \\
\text { Protection and restoration of the geosites to } \\
\text { study and disseminate the mining-industrial } \\
\text { history of the country. } \\
\text { Proposals for base projects for future initia- } \\
\text { tives of a Geopark ('Ruta del Oro') } \\
\text { Through the project Geopark 'Ruta del Oro', } \\
\text { work sources are created. } \\
\text { Projects of governmental entities and agree- } \\
\text { ments with universities for the recovery of } \\
\text { geosites and promulgate geotourism. } \\
\text { A tourist development susceptible to im- } \\
\text { prove. }\end{array}$ \\
\hline Weaknesses & Threats \\
\hline $\begin{array}{l}\text { Despite its geotouristic importance, certain } \\
\text { sites look neglected. } \\
\text { Little support from government entities for } \\
\text { the conservation of these geosites. } \\
\text { Weak conservation awareness in places of } \\
\text { relevance. } \\
\text { Lack of teaching content and links with } \\
\text { interested universities for development } \\
\text { plans. } \\
\text { Lack of informative content in mining- } \\
\text { industrial heritage places of interest. } \\
\text { Lack of 'social awareness' that requires } \\
\text { industrial heritage. }\end{array}$ & $\begin{array}{l}\text { Extinction of sites of mining-industrial } \\
\text { heritage interest. } \\
\text { Contamination of water sources due to bad } \\
\text { mining practices that affect the population. } \\
\text { Lack of investment to preserve, restore and } \\
\text { value the Heritage. } \\
\text { Geosites abandoned and little valued by the } \\
\text { community. } \\
\text { High level of vulnerability in places of in- } \\
\text { dustrial heritage interest and loss of value. } \\
\text { Problems related to the use of the land and } \\
\text { its natural environment. }\end{array}$ \\
\hline
\end{tabular}

in the mine-closing process are enabled and are a major factor in the cleaner energy production as mining infrastructure and galleries can be very important in providing: (a) safe sites for alternative uses, (b) runoff outlets from treated and environmentally friendly waters, (c) uses of spaces for the development of the city and the sector, (d) use of underground spaces for geotourism, (e) use of waterfalls for hydroelectric power production, (f) use of old galleries for ventilation systems, and other alternatives and uses that register an environment in good condition and a clean energy production for the sector.

The results presented through a SWOT analysis were obtained from the focal group work and its feedback with the Sustainable Development Goals (SDG) and geotourism perspectives issues in the upper part of El Oro province, Zaruma-Portovelo.

The result of the analysis in Table 3 is a useful tool for the preparation of the TOWS matrix in Table 4, which summarizes the following general strategies, considering internal characteristics (strengths and weaknesses) and external characteristics (opportunities and threats). 
Table 4: TOWS matrix of the Workshop 'Geotourism prospects in the upper part of the El Oro province, Zaruma-Portovelo'.

\begin{tabular}{|c|c|}
\hline Strategies: Strengths + Opportunities & Strategies: Weaknesses + Opportunities \\
\hline $\begin{array}{l}\text { 2.a,b Restorations that 'put in value' the } \\
\text { elements considered of greater attraction } \\
\text { to highlight the authenticity of the geosites } \\
\text { and expand the tourist offer. } \\
\text { 3.e,f Encourage the authority's commitment } \\
\text { and responsibility for the formulation of } \\
\text { tourism projects with short-term implemen- } \\
\text { tation plans. } \\
\text { 6.c,d Implementation of new tourism initia- } \\
\text { tives for the local development of the min- } \\
\text { ing area such as the creation of a geopark. }\end{array}$ & $\begin{array}{l}\text { 1.f Adapt the infrastructure of services } \\
\text { annexed to the mining site (roads, signage, } \\
\text { recreational areas, etc.) to improve the } \\
\text { quality of life of the population and the } \\
\text { satisfaction of tourists during their stay. } \\
\text { 4.b Development of programs by edu- } \\
\text { cational institutions, public and private } \\
\text { companies in the sector to raise awareness } \\
\text { of the values of industrial-mining heritage, } \\
\text { its importance of recovery, conservation, } \\
\text { and dissemination. } \\
\text { 5.a To make agreements with universities } \\
\text { for management works such as georuts, } \\
\text { mine theme parks and geoparks. }\end{array}$ \\
\hline Strategies: Strengths + Threats & Strategies: Weaknesses + Threats \\
\hline $\begin{array}{l}\text { 4.c Work of multidisciplinary groups to } \\
\text { contribute with a plan for the recovery of } \\
\text { mining-industrial sites and their enhance- } \\
\text { ment for sustainable development. } \\
\text { 5.f Encourage the consolidation of mining- } \\
\text { industrial places of interest according to the } \\
\text { conservation status validated in this work to } \\
\text { enhance them as tourist destinations. }\end{array}$ & $\begin{array}{l}\text { 5.a.e Implement promotion strategies (mar- } \\
\text { keting) so that these sites are not forgotten } \\
\text { by the community itself and disseminate its } \\
\text { informative content and importance in the } \\
\text { country's mining history. } \\
\text { 2.c Look for investors to develop a pro- } \\
\text { posal that comes from the community itself } \\
\text { and reveals their identity. }\end{array}$ \\
\hline
\end{tabular}

\section{CONCLUSIONS}

The study reveals the existence of places of high mining-industrial heritage interest in the Zaruma-Portovelo district. It follows the example of similar initiatives launched in some European countries. These sites could be exploited through local development strategies. In this way, it is essential to take adequate legal and financial measures to materialize the viability of mining-industrial uses in any of the exploitation figures. Thus, the sites could contribute to socio-economic and geotouristic development. In mining, the extraction of gold and the problems derived from related activities such as environmental problems and land destabilization require alternative development strategies such as those mentioned in the 'Discussion' section. Geotourism represents a sustainable activity, which is also compatible with other current socio-economic activities in the area. For this purpose, it is necessary to raise awareness among the population through educational programs, workshops, and talks related to heritage and culture. These strategies could serve as an incentive to promote what is known, they could be the key to sustainable socio-economic and environmental development.

\section{REFERENCES}

[1] Campoverde, C., Ramírez, G., Carrión, P. y Herrera, G., Zaruma-Portovelo: Contexto geominero de patrimonio y diversidad para el desarrollo sostenible. Libro de Actas del Cuarto Congreso Internacional sobre geología y minería ambiental para el orde- 
namiento del territorio y el desarrollo, pp. 163-186, ed. Geoparque de la Comarca de Molina-Alto Tajo, SIGMADOT Y SEDGYM, 2016. (In Spanish)

[2] Ramírez G., Campoverde C. y Carrión P., Potencial geoturístico-minero de la Ruta del Oro, Ecuador. Libro de Actas del Cuarto Congreso Internacional sobre geología y minería ambiental para el ordenamiento del territorio y el desarrollo, pp. 213-230, ed. Geoparque de la Comarca de Molina-Alto Tajo, SIGMADOT Y SEDGYM, 2016. (In Spanish)

[3] Boivin M. \& Tanguay Georges A., Analysis of the determinants of urban tourism attractiveness: The case of Québec City and Bordeaux. Journal of Destination Marketing \& Management XI, ScienceDirect, pp. 67-79, ed. Elsevier, marzo, 2019. https://doi. org/10.1016/J.JDMM.2018.11.002

[4] Sanmartín G. M., Zhigue A.R. y Muññoz G., Environmental managemet for the conservation of Zaruma, historical and cultural heritage of Ecuador. Revista Conrado, 13 (1-Ext), pp. 116-121, 2017.

[5] Carrión P., Herrera G., Briones J., Caldevilla P., Domínguez M.J. y Berrezueta E., Geotourism and Development Base on Geological and Mining Site Utilization, ZarumaPortovelo, Ecuador, Geosciences, vol. 8, Issue 6, June 2018. https://doi.org/10.3390/ geosciences 8060205

[6] Villafuerte I., Barrazueta A. y Corral C., Desarrollo Turístico de la Ruta del Oro y su área de influencia en los cantones Zaruma y Portovelo, Tesis, 2005. (In Spanish)

[7] Oviedo B., El Patrimonio Industrial Minero del Archivo Histórico y Museo de Minería, Asociación Civil y la Carta de Nixhny Tagil. ICOMOS- México AC, 2015. (In Spanish)

[8] Paz B., Calderón B. y Ruiz H., La Gestión Territorial del Patrimonio Industrial en Castilla y León (España): fábricas y paisajes. Investigaciones Geográficas, Boletín del Instituto de Geografía, UNAM, para ser publicado. (In Spanish)

[9] Nuñez P., Vejsbjerg L., El Turismo entre la Actividad Económica y el Derecho Social El Parque Nacional Nahuel Huapi, Argentina, 1934-1955. Estudios y Perspectivas en Turismo, Universidad Nacional de Rio Negro- Argentina, vol. 19, pp. 930-945, 2010. (In Spanish)

[10] Castillo A., López T. y Vázquez G., El turismo industrial minero como motor de desarrollo en áreas geográficas en declive. Un estudio de caso. Estudios y Perspectivas en Turismo. Universidad de Córdoba-España, vol. 19, pp. 382-393, 2010. (In Spanish)

[11] Sandoval F., Albán J., Carvajal M., Chamorro C., y Pazmiño D., Minería, Minerales y Desarrollo Sustentable en Ecuador, Ambiente y Sociedad, Informe Nacional MMSDEcuador, cap. 7. (In Spanish)

[12] Domínguez I., Costa V. y Guardado R., La comunicación en el patrimonio geológico minero: un enfoque desde la minería del cromo en Moa. Minería y Geología, vol. 31 n.3, pp. 128-139, ISSN 19938012, julio-septiembre, 2015. (In Spanish)

[13] Montero J. \& Salazar Y., La reinserción laboral tras el cierre de minas: una vía para lograr el desarrollo sustentable en la minería. Minería y Geología, vol. 27 n.4, pp. 64-87, ISSN 19938012, octubre-diciembre, 2011. (In Spanish)

[14] Fernández G. \& Guzmán A., El patrimonio industrial-minero como recurso turístico cultural: El caso de un pueblo-fábrica en Argentina, PASOS Revista de Turismo y Patrimonio Cultural, vol. 2 N. 1, pp. 101-109, 2004. https://doi.org/10.25145/j. pasos.2004.02.008. (In Spanish)

[15] Ministerio de Industrias y Productividad, Coordinación Zonal 7, Plan estratégico emergente de recuperación y fomento productivo de los cantones, diciembre, 2017. (In Spanish) 
[16] Moscoso J., Política Pública de Reparación Integral. Estudio de caso en el Distrito Minero Zaruma-Portovelo, Provincia de El Oro, Disertación previa a la obtención del título de sociólogo, con mención en desarrollo, Pontificia Universidad Católica del Ecuador, 2015. (In Spanish)

[17] Valladares R. Y., Dal Pozzo F. y Castillo A. J., Propuesta metodológica para definir la vocación minera en el contexto del ordenamiento territorial venezolano. Boletín Geológico y Minero, 126 (4), pp. 663-676, ISSN 0366-0176, 2015. (In Spanish)

[18] Orche E., Parques mineros, desarrollo sostenible y ordenación del territorio. Integración de la minería en la ordenación del territorio. ESPOL-CYTED-CICYT. Guayaquil, pp. 112-124, 2003. (In Spanish)

[19] Orche E., Puesta en valor del patrimonio geológico-minero: el proceso de adaptación de explotaciones mineras a parques temáticos. Patrimonio geológico y minero en el contexto del cierre de minas. CETEM-CYTED-IMAAC-CNPq. Río de Janeiro, pp. 51-65, 2003. (In Spanish)

[20] Guerrero-Almeida, D., Chacón Pérez, Y., Fonseca Hernández, D. y Court-Potrillé, M. Metodología para la ejecución de un cierre de minas sustentable. Minería y Geología. Online https://www.redalyc.org/articulo.oa?id=223532481006, 30(3), pp. 85-103, 2014. Accessed on: 16 Aug. 2019. (In Spanish)

[21] Carrión P., Amos V., Ladines L., Loayza G., Domínguez M. J. y Berrezueta E. La ruta del Oro y el Patrimonio geológico-minero en Zaruma-Portovelo (Ecuador). IV Congreso Internacional sobre Patrimonio Geológico y Minero, S-2, C-09, pp. 333-346, Ultrillas- 2003. (In Spanish)

[22] Alberruche del Campo E., Marchán C., Sánchez A., Ponce D. y García A. Guía metodológica para la integración del Patrimonio Minero en la Evaluación de Impacto Ambiental. Encomienda de gestión de trabajos en materia de impacto ambiental y de producción y consumo sostenible, Instituto Geológico y Minero de España; Ministerio de Agricultura, Alimentación y Medio Ambiente, 40 págs., 2012. (In Spanish)

[23] National Secretary of Planning and Development and National Information System, Information for planning and territorial planning, National Geographic Atlas, 2013. http://sni.gob.ec/atlas-geografico-nacional-2013

[24] Murillo Carrión R. La Colonia: una época de transición. Zaruma, historia minera Identidad en Portovelo, cap. I, ed. BRYA-YALA. Docutech Quito-Ecuador, 2000. (In Spanish) 